\title{
Simulation of Freezing-thawing Cycles in a Permafrost Microcosm for Assessing Microbial Methane Production under Extreme Conditions
}

\author{
D. Wagner, ${ }^{*}$ C. Wille, S. Kobabe and E.-M. Pfeiffer
}

Alfred Wegener Institute for Polar and Marine Research, Potsdam, Germany

\begin{abstract}
The microbial process of methane $\left(\mathrm{CH}_{4}\right)$ production during the back-freezing of permafrost soils in autumn and the future fate of produced $\mathrm{CH}_{4}$ in the thawing phase of the following spring are not well understood. Long-term $\mathrm{CH}_{4}$ flux studies in the Lena Delta (Siberia) indicate that back-stored $\mathrm{CH}_{4}$ adds to the emission of newly-produced $\mathrm{CH}_{4}$ at the beginning of the vegetation period. Further field analysis shows that microbial $\mathrm{CH}_{4}$ production already occurs at in situ temperatures of around $1{ }^{\circ} \mathrm{C}$ in the bottom layer of the soil. Therefore, a permafrost microcosm was developed to simulate the influence of the annual freezing-thawing cycles on the $\mathrm{CH}_{4}$ fluxes in the active layer of permafrost soils. Two cryostats ensure independent freezing and thawing the top and the bottom of the microcosm to simulate different field conditions. The $\mathrm{CH}_{4}$ concentration (Rhizon soil moisture samplers), the soil temperature (film platinum resistance temperature detectors [RTDs]) and the soil water content (time domain reflectometry) are analysed in different depths of the microcosm during the simulation in addition to the concentration of emitted $\mathrm{CH}_{4}$ in the headspace of the microcosm. The data obtained contribute to the understanding of microbial processes and $\mathrm{CH}_{4}$ fluxes in permafrost environments in the autumn and early winter. Copyright (C) 2003 John Wiley \& Sons, Ltd.
\end{abstract}

KEY WORDS: methane production; winter methane fluxes; freezing-thawing cycles; permafrost microcosm

\section{INTRODUCTION}

High-latitude wetlands are natural sources of methane $\left(\mathrm{CH}_{4}\right)$, which is one of the important climate-relevant trace gases in the Earth's atmosphere (Wuebbles and Hayhoe, 2002). Methane emission rates from tundra environments show large variations, ranging between 20 and $40 \mathrm{Tg} \mathrm{CH}_{4} \mathrm{yr}^{-1}$ (Christensen et al., 1996). Winter methane fluxes have been estimated only in North America and West Siberia (Whalen and Reeburgh, 1988; Dise, 1992; Melloh and Crill, 1996; Panikov and Dedysh, 2000). The reported winter emission rates amount to between $4-41 \%$ of the annual methane fluxes. Friborg et al. (1997) observed a drastic

\footnotetext{
* Correspondence to: D. Wagner, Alfred Wegener Institute for Polar and Marine Research, Telegrafenberg A 43, 14473 Potsdam, Germany. E-mail: dwagner@awi-potsdam.de
}

increase of $\mathrm{CH}_{4}$ release from a subarctic mire during the thawing period, which reached approximately $25 \%$ of the mid-summer flux. The close relationship between $\mathrm{CH}_{4}$ fluxes and the microbiological processes of $\mathrm{CH}_{4}$ production and oxidation in permafrost soils was reported by Wagner et al. (2003).

Methane fluxes from natural wetlands are basically caused by two microbiological processes: (i) methane production by methanogenic archaea in the anaerobic soil horizons and (ii) methane oxidation by methanotrophic bacteria in the aerobic soil horizons (Hanson and Hanson, 1996; Garcia et al., 2000). In permafrost habitats microbial activity is influenced by extreme gradients in temperature, moisture and chemistry (see review in Wagner et al., 2001b). In spite of the extreme conditions of permafrost soils, methane production was revealed by in situ studies of the active layer with temperature ranges between about $10^{\circ} \mathrm{C}$ to Received 15 February 2003 Revised 26 June 2003 Accepted 4 July 2003 
$1{ }^{\circ} \mathrm{C}$ (Samarkin et al., 1999; Wagner et al., 2003). However, methane production and oxidation rates during back-freezing of the active layer in autumn and the future fate of produced methane in the thawing phase of the following spring are not well understood.

In this paper, we describe a new technique for the simulation of natural freezing-thawing cycles of the active layer in a permafrost microcosm. The core temperature, moisture and methane concentration and release in different depths of the microcosm can be measured continuously under controlled freezing and thawing conditions. The simulation experiment provides an insight into the activity of microorganisms and turnover rates under various cryogenic conditions (i.e. frozen, partly frozen, unfrozen).

\section{MATERIAL AND METHODS}

\section{Field Investigations}

The field investigations during the expeditions LENA 1999 and LENA 2000 (Pfeiffer et al., 2000; Wagner et al., 2001a) were carried out on Samoylov island $\left(72^{\circ} 22 \mathrm{~N}, 126^{\circ} 28 \mathrm{E}\right)$ located in the Lena Delta, Siberia. The study site represents an area of typical polygonal patterned ground with ice-wedges. The permafrost soils are classified according to the US Soil Taxonomy (Soil Survey Staff, 1998) as Glacic Aquiturbels and Typic Historthels with a maximum thaw depth of between 30 and $55 \mathrm{~cm}$. The average air temperature in 1999 was $-14.7^{\circ} \mathrm{C}$ with a minimum in January $\left(-47.8^{\circ} \mathrm{C}\right)$ and a maximum in July $\left(+18.3^{\circ} \mathrm{C}\right)$.

Methane flux measurements were conducted daily at midday between the end of May and the beginning of September 1999, and in August 2000. Five static chambers (PVC transparent, 12.51) installed close to each other in a polygon depression were used. The condition of the chambers, the realization of the measurements and the site characteristics are described in detail by Wagner et al. (2003). Methane emissions were calculated from the chamber volume and the linear increase in methane concentration.

Microbial methane production was studied in the bottom layer of the polygon depression in July 1999. Fresh soil material $(20 \mathrm{~g})$ from the bottom layer was weighed into 100-ml glass jars and closed with a screw cap containing a septum. The samples were evacuated and flushed with ultra pure $\mathrm{N}_{2}$. The prepared soil samples were re-installed in the bottom layer of the soil profile from which the samples had been taken. Three replicates were used. Gas samples were taken every $24 \mathrm{~h}$ out of the jars headspace with a gastight syringe. Methane production rates were calculated from the linear increase in $\mathrm{CH}_{4}$ concentration analysed by gas chromatography.

\section{Simulation Experiment}

Back-freezing and thawing of the active layer was simulated with an upgraded apparatus formerly applied for studying changes of the soil structure as a function of freezing processes (Müller-Lupp, 2002). The new configuration of the microcosm allows measurement of the in situ $\mathrm{CH}_{4}$ concentration (or the concentration of other relevant gases like $\left.\mathrm{CO}_{2}\right)$ at different core depths and the concentration of the emitted $\mathrm{CH}_{4}$ in the headspace of the microcosm. The data obtained can be used for the calculation of $\mathrm{CH}_{4}$ turnover rates.

The permafrost microcosm was prepared from an undisturbed soil core including the plant cover, taken from the active layer of a permafrost soil (e.g. Typic Historthel) in the depression of a low-centred polygon in the Lena Delta, Siberia. The soil core was characterized by its natural structure, pore system and water content. Different states of the active layer (frozen, partly frozen, unfrozen) and varying freezing times were simulated. Variations in the duration of freeze-thaw cycles and their influence on the microbiological activity can then be studied. During the experiment, the temperature, moisture and $\mathrm{CH}_{4}$ concentration were determined at $5-\mathrm{cm}$ intervals of the microcosm.

The permafrost microcosm consists of a Plexiglas tube accommodating the undisturbed soil core (Figure 1). The tube is closed gastight by an upper

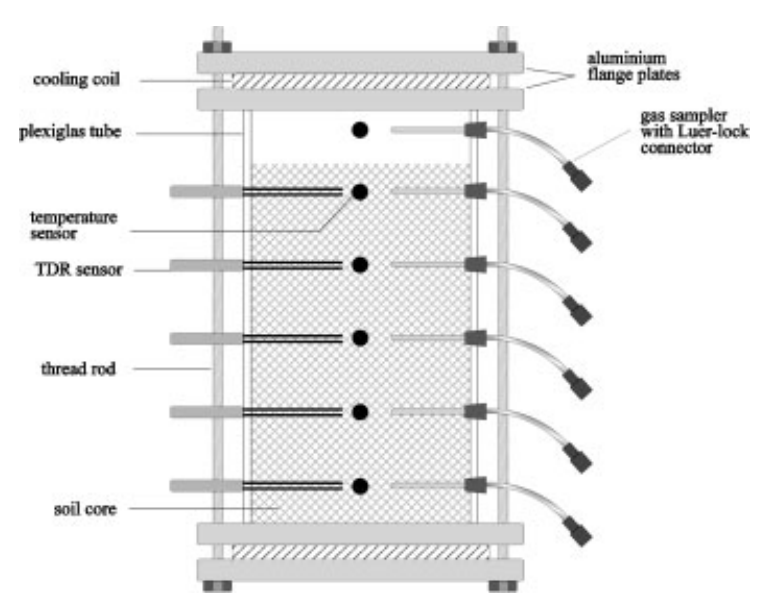

Figure 1 Schematic view of the permafrost microcosm (height $=$ $30 \mathrm{~cm}$, inner diameter $=10 \mathrm{~cm}$ ). 
and lower flange plate. The Plexiglas tube has a length of $30 \mathrm{~cm}$, an inner diameter of $10 \mathrm{~cm}$ and a wall thickness of $0.5 \mathrm{~cm}$. One side of the tube wall was cut open and the slot was filled with a polyurethane elastomer. In this way, the tube wall can be exactly adjusted to the undisturbed permafrost core using pipe clamps without influencing the gastightness of the microcosm. The flanges consist of two aluminium plates with a cooling coil between. The aluminium plates facing the soil core incorporate a rubber seal to make a gastight connection to the Plexiglas tube.

For the insertion of temperature sensors, water content probes (time-domain-reflectometry), and gas samplers, the Plexiglas tube is prepared with compatible holes. The holes are placed at a distance of $120^{\circ}$ around the tube, while the vertical distance between the holes is $5 \mathrm{~cm}$. In order to establish a gastight connection to the Plexiglas tube, the temperature sensors and gas samplers are glued into conical rubber stoppers which are plugged into the holes. The TDR probes have special thread flanges which are screwed into the tube wall and sealed with a polyurethane elastomer.

The installation of the permafrost microcosm is carried out in a cooling chamber at $4^{\circ} \mathrm{C}$. The soil core is transferred to the Plexiglas tube in a frozen condition. The core is arranged exactly aligned with the bottom side of the tube and then clamped by reducing the tube's diameter with metal clamps. The flange plates and the tube are then closed gastight using four threaded bolts.

Five temperature sensors and gas samplers were inserted into the frozen soil, after adequate holes were drilled through the openings in the Plexiglas. Additionally, one temperature sensor and one gas sampler were installed in the headspace above the soil core. Finally, the microcosm was left in the cooling chamber to thaw the soil core. Afterwards, TDR probes were plugged into the soft soil substrate.

Two Thermo Haake cryostats (C10-K15 and WKL26; Karlsruhe, Germany) were used to freeze the permafrost microcosm by flowing a coolant through the coils in the flanges. Two cooling circuits ensured different cooling rates and temperatures for the flanges at the top and bottom of the microcosm.

Measurements of volumetric water content were carried out using a Campbell Scientific TDR Loughborough, UK) system, which consisted of a CR10 data logger and a Tektronix $1502 \mathrm{C}$ TDR cable tester. The TDR probes used for the simulation were two-rod, $75 \mathrm{~mm} \mathrm{LP} / \mathrm{ms}$ laboratory probes from EASY TEST Ltd. (Lublin, Poland). The distance between the rods was $4.3 \mathrm{~mm}$ and the rod diameter was $0.8 \mathrm{~mm}$.
Gas samples were taken with Rhizon soil moisture samplers (Rhizosphere Research Products, Wageningen, The Netherlands). The sampler consisted of a porous polymer tube of $50 \mathrm{~mm}$ length and an outer diameter of $2.5 \mathrm{~mm}$ connected to a PVC tube and a septum, which was handmade from Luer-lock components. A stainless steel wire inside the polymer and PVC tubes provided support. The dead volume of the sampler was $0.5 \mathrm{ml}$. Gas samples could be taken with a gastight syringe through the septum for direct analysis by gas chromatography.

Temperature measurements were made with thin film platinum RTDs (Honeywell HEL-705-U). These sensors have cylindrical ceramic cases of $2.2 \mathrm{~mm}$ in diameter and $5 \mathrm{~mm}$ in length.

In order to simulate the natural freezing-thawing cycles of permafrost soils, the microcosm could be independently frozen downwards and upwards from the top and bottom side. Furthermore, it was possible to adjust the freezing process on the top and on the bottom side of the microcosm to the planned test sequence (see below) using two separate cooling circuits (Figure 1).

The simulation experiment begins in unfrozen conditions. Therefore, the permafrost microcosm was incubated in the cooling chamber for about $48 \mathrm{~h}$ at $4^{\circ} \mathrm{C}$ to calibrate the system. Two different simulation experiments can be performed: (i) the soil is completely frozen and thawed again or (ii) the soil is partly frozen downwards and upwards from the top and bottom side leaving a central zone which remains unfrozen (Figure 2). Another option is to vary the duration of the individual experimental phases. For example, the period of final freezing can be varied, in order to simulate the seasonal influence on microbial activity during back-freezing of the active layer. In general, a simulation cycle consisted of three to five freezing-thawing phases to ensure statistical significance of the experiment.

During the experiment in the cooling chamber, the microcosm was kept in a Styrofoam box. Measurements of temperature and water content were automatically logged at time steps of $15 \mathrm{~min}$. Gas samples were manually taken with a gastight syringe and analysed with a gas chromatograph. A simulation experiment with three freezing-thawing cycles lasted between two and six weeks depending on the soil type and its water content.

Further applications of the permafrost microcosm are in progress to investigate the methane production pathways by either using ${ }^{14} \mathrm{C}$-labelled substrates (bicarbonate, acetate or plant material) or by variation of environmental conditions (e.g. the water content or radiation). 


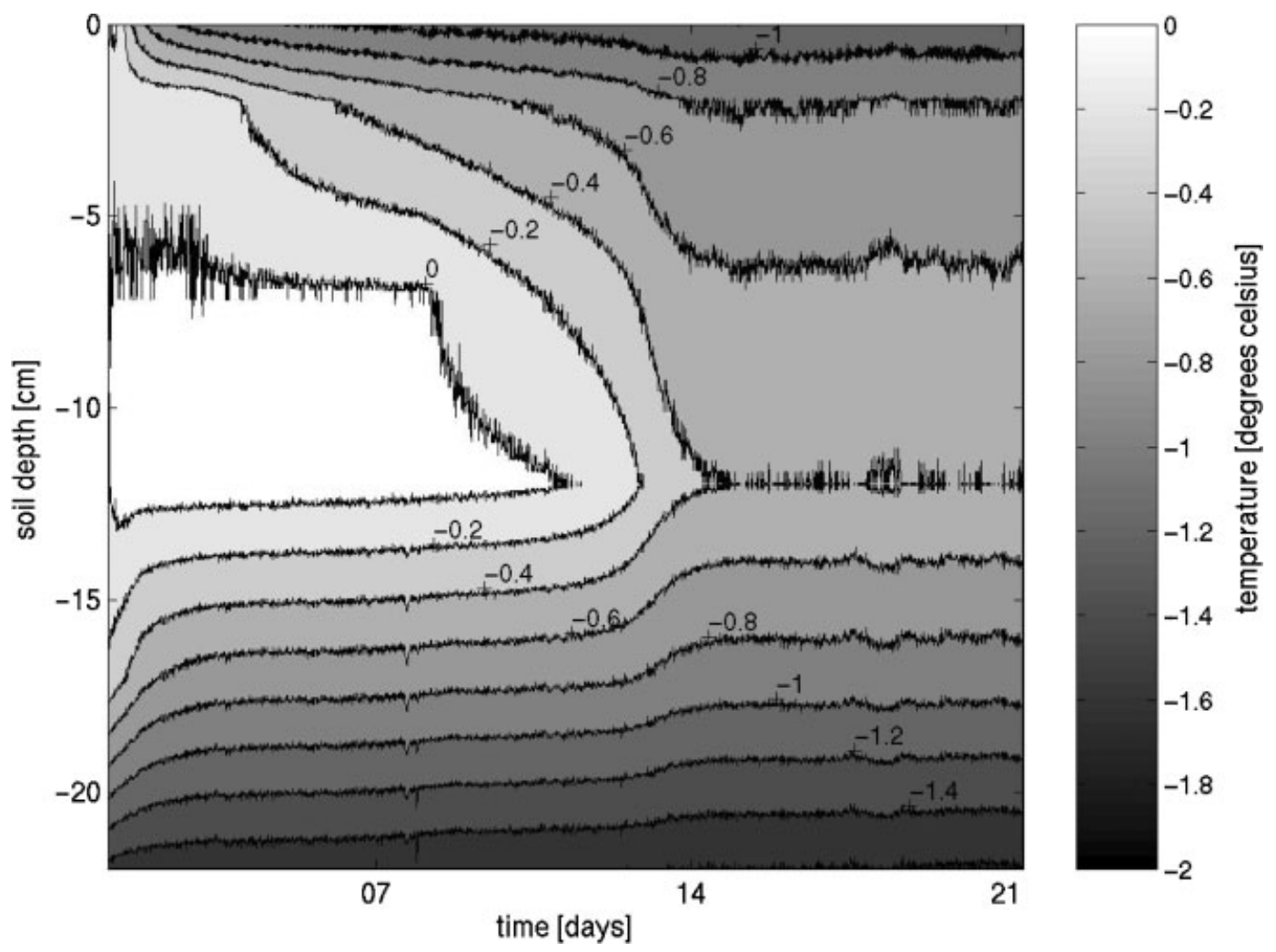

Figure 2 Temperature profile of the soil core during a freezing process (soil depth $0 \mathrm{~cm}=$ headspace above soil core).

\section{Methane Analysis}

The $\mathrm{CH}_{4}$ concentrations in the field experiments and during the simulation experiments were determined with a gas chromatograph (Chrompack GC 9003). The instrument was equipped with a Poraplot Q (100/ 120 mesh, $20 \mathrm{ft}$ ) capillary column, which operates with pure helium as carrier gas at a flow rate of $20 \mathrm{ml} \mathrm{min}^{-1} \cdot \mathrm{CH}_{4}$ was analysed by a flame ionisation detector. The injector/detector temperatures were set at $160^{\circ} \mathrm{C}$ and the column oven at $80^{\circ} \mathrm{C}$. All gas sample analyses were done after calibration with standard gases.

\section{RESULTS AND DISCUSSION}

\section{Field Investigations}

The $\mathrm{CH}_{4}$ fluxes of the polygon depression measured in 1999 showed, right from the start of the soil thawing at the end of May, a continuously increasing flux rate, which reached the highest values in mid-July (Figure 3). In the course of the season, $\mathrm{CH}_{4}$ fluxes decreased again and attained a relatively constant rate in August, when the maximum thawing depth of the active layer was reached. However, the $\mathrm{CH}_{4}$ release in August 1999 and 2000 revealed erratic fluctuations, which differ clearly from the emission process at the beginning of the season (Figures 3 and 4). Statistical analysis indicated a significant correlation $(r=0.94$, $p<0.0001$ ) between $\mathrm{CH}_{4}$ release and thawing of the

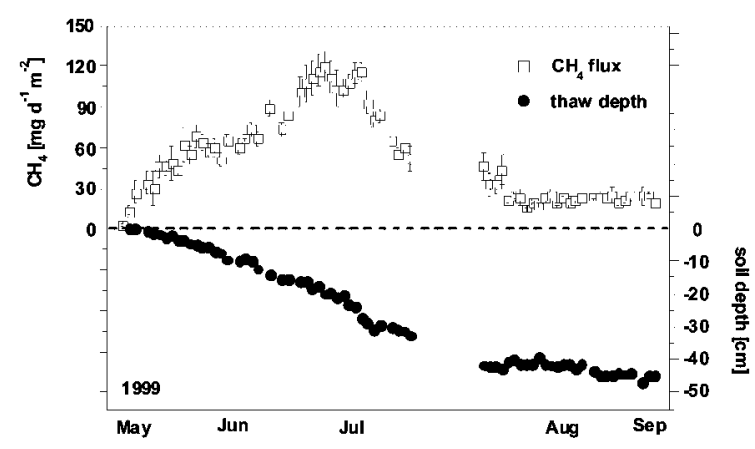

Figure $3 \mathrm{CH}_{4}$ flux and thaw depth of the polygon depression measured from the beginning of May to the beginning of September 1999 on Samoylov Island, Lena Delta (means \pm SE, $n=5$ ). 


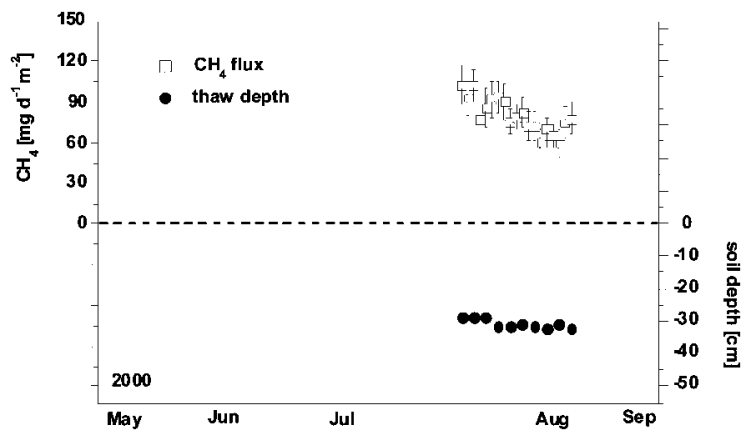

Figure $4 \quad \mathrm{CH}_{4}$ flux and thaw depth of the polygon depression measured in August 2000 on Samoylov Island, Lena Delta (means \pm SE, $\mathrm{n}=5$ ).

active layer for the early vegetation period from the end of May to the middle of July.

Further field studies of the microbial processes showed significant activity of the methane-producing microflora in the boundary of the frozen ground (Figure 5). This layer was characterized by an in situ temperature between 0.6 and $1.2^{\circ} \mathrm{C}$. The measured soil temperature on our long-term study site in

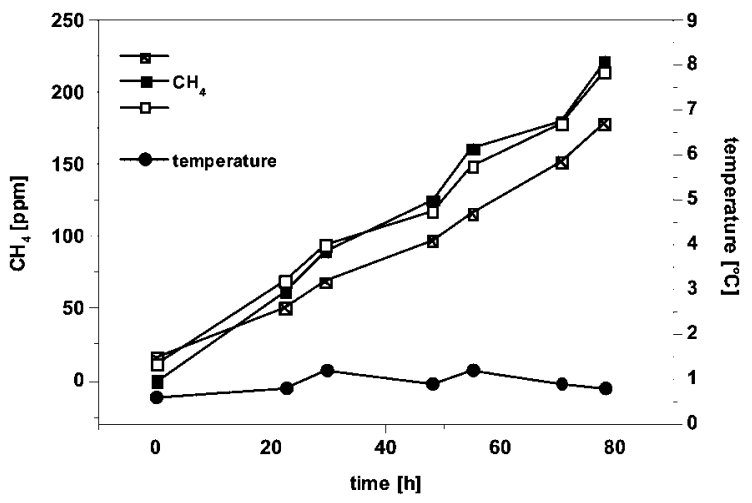

Figure 5 Microbial $\mathrm{CH}_{4}$ production (three replicates) and in situ temperature in the boundary to the frozen ground of the polygon depression. The field experiment was carried out between 5 and 12 July 1999 on Samoylov Island, Lena Delta.

the Lena Delta (Boike et al., 2003) showed that a soil zone persisted until the middle of October 1998 with temperatures between 0.5 and $0{ }^{\circ} \mathrm{C}$ (Figure 6). These are temperatures in which unadapted microorganisms are inactive (Morita, 1975). Due to our analyses of

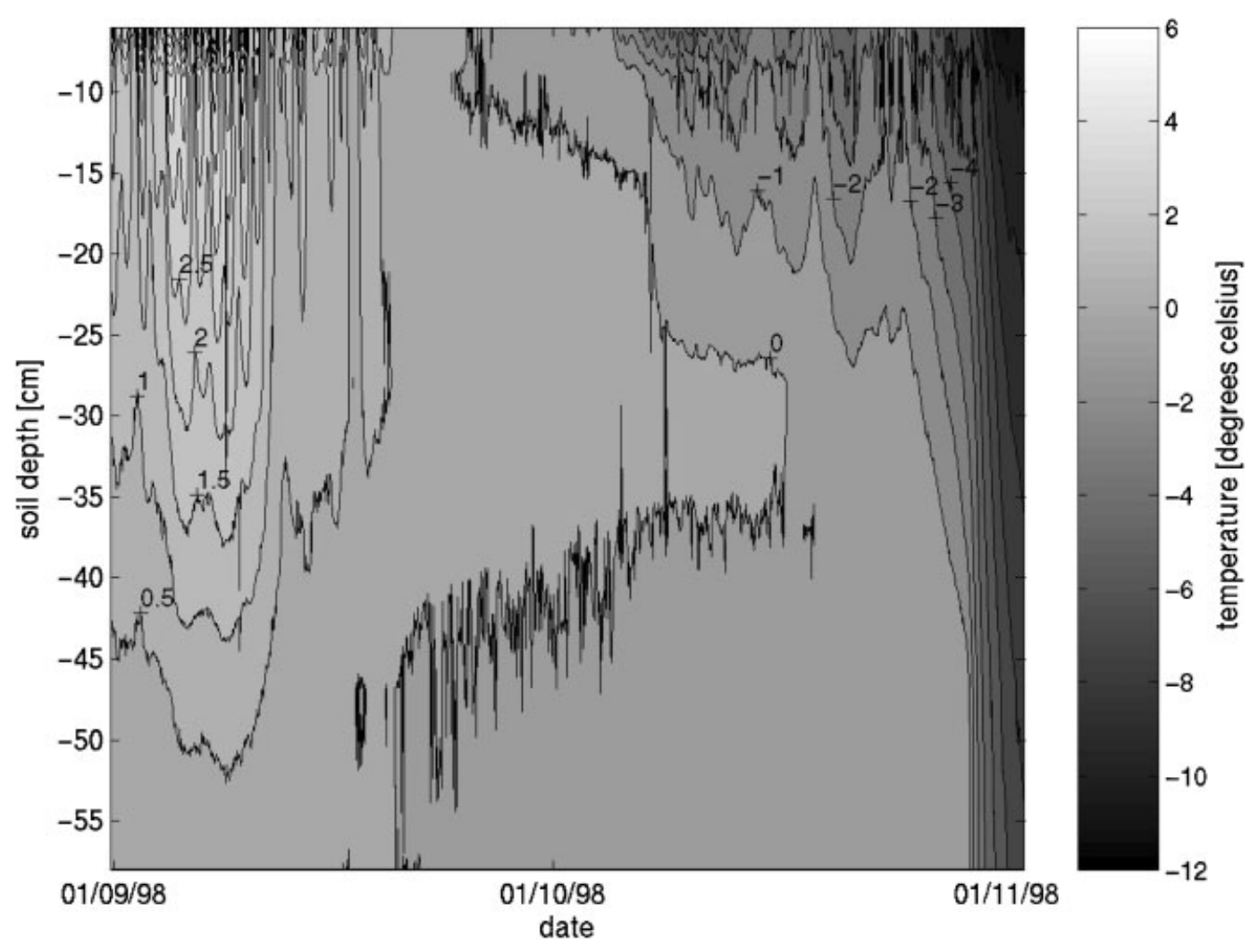

Figure 6 Temperature profile in the active layer of the polygon depression from the beginning of September to the beginning of November 1998 (Lena Delta, Siberia). 


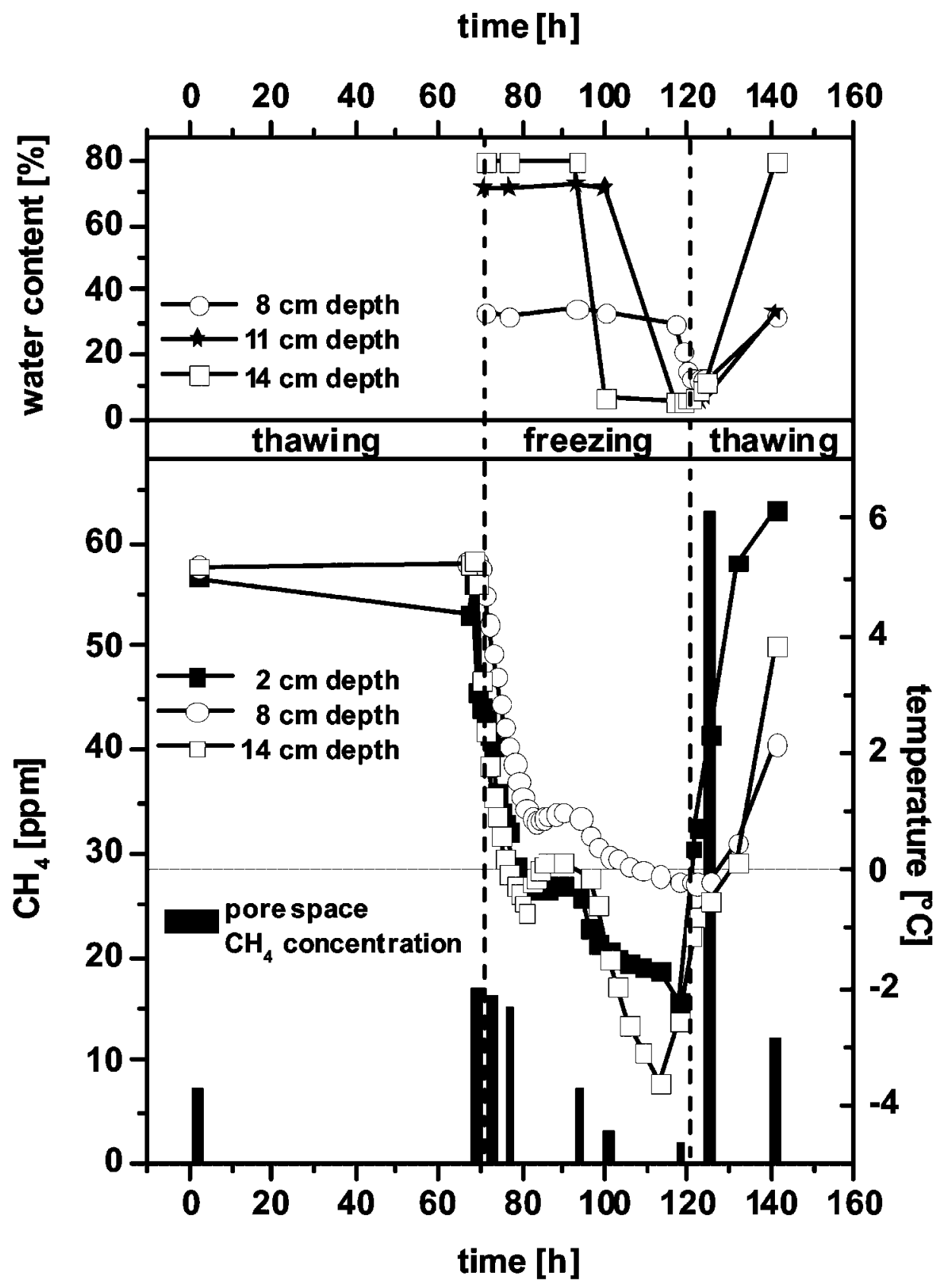

Figure 7 Water content, temperature and methane concentration during a preliminary test sequence of a freezing-thawing cycle in a forerunner model (modified after Müller-Lupp, 2002) of the described permafrost microcosm.

microbial activity it can be assumed that methane still formed up to the complete back-freezing of the active layer. In contrast to earlier assumptions, methane is produced not only during the vegetation period but also in the cold transitional season. This methane is kept enclosed in the active layer during the backfreezing process and is released in the thawing phase of the following spring. Samarkin et al. (1999) already assumed that such back-stored methane adds to the emission of newly-produced methane. Both the currently-formed methane and the back-stored methane from the year before determine the characteristic increase of trace-gas release observed at the beginning of the season 1999 (Figure 3). 
Permafrost soils are characterized by extreme variation in temperature (Yershov, 1998). Many microorganisms are able to survive in cold permafrost sediments, but this adaptation can be either a tolerance or a preference. In accordance with Panikov (1997), psychrophilic bacteria are a significant part of the microbial community in cold permafrost soils. Our results indicate the existence of a methane-producing microflora which is adapted to low in situ temperatures of permafrost-affected soils.

The seasonal variation of soil temperature also influences the availability of pore water. The presence of unfrozen water is an essential bio-physical requirement for the activity of microorganisms in permafrost. Temperatures below zero stand for an increasing loss of water. At the same time, freezing of water leads to an increase in salt content in the remaining pore solution. Nevertheless, permafrost soils are known to contain significant amounts of unfrozen water (Boike et al., 1998). The most important feature of this water is the possible transfer of ions and nutrient (Ostroumov and Siegert, 1996). Therefore, the microflora in permafrost soils and sediments is influenced by changing gradients. These gradients, especially those of temperature and water content, are considered in the simulation experiment.

To understand the carbon cycle in permafrost environments in the off-peak season further research is needed. Field studies are difficult to accomplish during the back-freezing of the active layer and necessary repetitions to validate results are often impossible in the same season.

\section{Simulation Experiment}

A preliminary test sequence in a forerunner model (modified after Müller-Lupp, 2002) of the described permafrost microcosm showed the relationship between soil temperature, water content and $\mathrm{CH}_{4}$ concentration during the freezing-thawing process (Figure 7). In the first $60 \mathrm{~h}$ the permafrost microcosm was incubated at $5^{\circ} \mathrm{C}$ to calibrate the system. Then the freezing cycle was started and the temperature was lowered to temperatures between $0^{\circ} \mathrm{C}$ and $4^{\circ} \mathrm{C}$ as a function of the core depth. At this time the water content decreased from $80 \%$ to about $10 \%$ and the $\mathrm{CH}_{4}$ concentration in the pore space decreased as well. After $120 \mathrm{~h}$ the thawing cycle was initiated again and immediately after thawing of the soil the highest $\mathrm{CH}_{4}$ concentration $(63 \mathrm{ppm})$ was analysed. These first data support the field observations that indicate methane production occurs in the unfrozen soil zone in autumn, which then leads to an inclusion of additional methane into the active layer. The new configuration of the microcosm presented in this paper ensures independent freezing and thawing the top and the bottom of the microcosm using two cooling circuits. This construction allows the simulation of different field conditions. Furthermore, $\mathrm{CH}_{4}$ production rates can be determined for different soil depth using gas samplers at each $5 \mathrm{~cm}$ of the microcosm.

Simulation experiments can give insights into the natural ecosystem and may yield important clues for the understanding of microbial life under extreme permafrost conditions. The use of undisturbed soil cores keep the original structure, pore system and stratification of the natural soil. The temperatures and water contents measured during the simulation can be adjusted with field data obtained from long-term measurements in the Lena Delta, Siberia (Boike et al., 2003). Thus, a direct correlation between the field conditions and the involved processes can be derived. Under this premise, the interaction between microorganisms and soil matrix can be assessed in a reasonable manner. The permafrost microcosm simulates the two freezing fronts (one from the top, one from the bottom) while the centre of the active layer remains unfrozen and methane production can still continue. Such freezing-thawing experiments can help to answer questions as to how the microbial population will be influenced by the natural permafrost system and how microorganisms interact with their environmental conditions.

\section{ACKNOWLEDGEMENTS}

We acknowledge the good collaboration among the members of the Russian-German field parties during the expeditions LENA 1999 and LENA 2000. Special thanks go to Waldemar Schneider for logistic support and Günter 'Molo' Stoof for technical assistance. In addition, we thank Dr B. Diekmann (Alfred Wegener Institute for Polar and Marine Research) for critical reading of the manuscript as well as Professor Anatoli Brouchkov (Hokkaido University) and an anonymous reviewer for their helpful comments on the manuscript.

\section{REFERENCES}

Boike J, Roth K, Overduin PP. 1998. Hydrological and thermal dynamics of the active layer (Taymyr Peninsula, Siberia). Water Resources Research 34: 355-363.

Boike J, Hinzman L, Overduin PP, Romanovsky V, Ippisch O, Roth K. 2003. A comparison of snow 
melt at three circumpolar sites: Spitzbergen, Siberia, Alaska. In Proceedings of the 8th International Conference on Permafrost, Zurich, Switzerland, 21-25 July 2003. Balkema Publishers: Lisse; 79-84.

Christensen TR, Prentice IC, Kaplan J, Haxeltine A, Sitch S. 1996. Methane flux from northern wetlands and tundra: an ecosystem source modelling approach. Tellus 48B: 651-660.

Dise NB. 1992. Winter fluxes of methane from Minnesota peatlands. Biogeochemistry 17: 71-83.

Friborg T, Christensen TR, Søgaard H. 1997. Rapid response of greenhouse gas emission to early spring thaw in a subarctic mire as shown by micrometeorological techniques. Geophysical Research Letters 24: 3061-3064.

Garcia J-L, Patel BKC, Ollivier B. 2000. Taxonomic, phylogenetic, and ecological diversity of methanogenic Archaea. Anaerobe 6: 205-226.

Hanson RS, Hanson TE. 1996. Methanotrophic bacteria. Microbiological Reviews 60: 439-471.

Melloh RA, Crill PM. 1996. Winter methane dynamics in a temperate peatland. Global Biogeochemical Cycles 10: $247-254$.

Morita RY. 1975. Psychrophilic bacteria. Bacteriological Review 39: 144-167.

Müller-Lupp W. 2002. Freeze and thaw in Siberian permafrost soils-methods and ecological relevance. Reports on Polar and Marine Research, AWI: Bremehaven; 415: 145.

Ostroumov VE, Siegert C. 1996. Exobiological aspects of mass transfer in microzones of permafrost deposits. Advances in Space Research 18: 79-86.

Panikov NS. 1997. A kinetic approach to microbial ecology in arctic and boreal ecosystems in relation to global change. In Global Change and Arctic Terrestrial Ecosystems, Oechel WC (ed.). Springer: Berlin; 171-188.

Panikov NS, Dedysh SN. 2000. Cold season $\mathrm{CH}_{4}$ and $\mathrm{CO}_{2}$ emission from boreal peat bogs (West Siberia): winter fluxes and thaw activation dynamics. Global Biogeochemical Cycles 14: 1071-1080.
Pfeiffer E-M, Wagner D, Becker H, Vlasenko A, Kutzbach L, Boike J, Quass W, Kloss W, Schulz B, Kurchatova A, Pozdnyakov VI, Akhmadeeva I. 2000. Modern processes in permafrost affected soils. In Russian-German Cooperation System Laptev Sea 2000: The Expedition LENA 1999, Rachold V, Grigoriev MN (eds). Reports on Polar and Marine Research, AWI: Bremehaven; 354; 22-54.

Samarkin VA, Gundelwein A, Pfeiffer E-M. 1999. Studies of methane production and emission in relation to the microrelief of a polygonal tundra in Northern Siberia. In Land-Ocean Systems in the Siberian Arctic, Kassens H, Bauch HA, Dmitrenko IA, Eicken H, Hubberten HW, Melles M, Thiede J, Timokhov LA (eds). Springer: Berlin; 329-342.

Soil Survey Staff. 1998. Keys to soil taxonomy. Eighth Edition. Soil Conservation Service, USDA: Washington, D.C.

Wagner D, Kurchatova A, Stoof G. 2001a. Modern processes in permafrost affected soils. In RussianGerman Cooperation System Laptev Sea 2000: The Expedition LENA 2000, Rachold V, Grigoriev MN (eds). Reports on Polar and Marine Research, AWI: Bremehaven; 388: 16-23.

Wagner D, Spieck E, Bock E, Pfeiffer E-M. 2001 b. Microbial life in terrestrial permafrost: methanogenesis and nitrification in Gelisols as potentials for exobiological processes. In Astrobiology: The Quest for the Conditions of Life, Horneck G, BaumstarkKhan C (eds). Springer: Berlin; 143-159.

Wagner D, Kobabe S, Pfeiffer E-M, Hubberten H-W. 2003. Microbial controls on methane fluxes from a polygonal tundra of the Lena Delta, Northeast Siberia. Permafrost and Periglacial Processes 14: 173-185.

Whalen SC, Reeburgh WS. 1988. A methane flux time series for tundra environments. Global Biogeochemical Cycles 2: 399-409.

Wuebbles DJ, Hayhoe K. 2002. Atmospheric methane and global change. Earth-Science Reviews 57: 177-210.

Yershov ED. 1998. General Geocryology. Cambridge University Press: Cambridge. 